tion, Menstruation, Gestation". The third contains papers dealing with the pituitary. The fourth is entitled "Régulations générales. Influence des facteurs nerveux et externes" ; and the fifth number contains papers on a variety of subjects such as pathology, toxicity, antihormones and cancer. The final publication of this material concludes the record of the colloquium, which will be long remembered by those taking part as a particularly happy and profitable occasion upon which La Fondation SingerPolignac should be most heartily congratulated.

\section{Lake District Roads}

Tre main object of the Friends of the Lake District is to have the Lake District made a National Park; but they insist on the necessity of guarding against the present tendency to undue development of motor-roads and motor-transport which would ruin the beauty and solitude of the district. The theme is developed at length in a pamphlet entitled "A Road Policy for the Lake District" published by the Friends of the Lake District, Ambleside. The essential Lake District is within a radius of some fifteen miles from the Langdale Pikes: this is the area that needs to be protected. There should be good motor-road access to this area and around it, but there should be no increase in the two or three good routes which go through this area. Moreover, in order to preserve the amenities, which give the Lake District much of its claim to preservation as a park, the width of roads should not be increased and through fast traffic thereby encouraged, dalehead roads which end in a cul-de-sac should not be made available for through traffic, and certain byroads should be closed entirely to motor-traffic. The pamphlet discusses these matters at length as well as the good and bad examples of road widening that have already been carried out. Above all, it advocates a policy that suits the requirements and amenities of the district rather than a standardized national policy which has little or no relation to local requirements.

\section{Insurance Against Natural Calamities}

THIS is a matter which has received a considerable amount of attention from time to time, and here and there premiums against such risk have been accepted, but in general, however, such risks are not taken by companies except for abnormally high premiums, for the simple reason that the place, time and destructive energy of the phenomena cannot be fore; told, nor do they occur with any regularity. The problem has been examined by $H$. Lanz-Stauffer (Revue pour l'étude des calamités, 1, No. 3 ; 1938). The first international conference on this topic, held in Paris on September 13-17, 1937, expressed the hope that research would be made into the problem of the application of the principles of insurance to natural calamities, an application considered until the present time not capable of realization. The author considers the problem from three different angles with regard to the Union Internationale de Secours: (1) with the Union as the insurer against the risk; (2) with the Union as the insured party against the risk; (3) with the Union encouraging in a general manner insurance against such calamities and contributing to its realization. The article may be commended to those concerned with insurance against damage by earthquakes, tornadoes and the like.

\section{Earthquakes Recorded at Tokyo}

WE have received the seismometrical report of the Earthquake Research Institute, Tokyo Imperial University, 1938, parts 1-2 (Jan. 1-June 30, 1938). This includes a first list of twelve stations attached to the Institute together with their latitude and longitude co-ordinates to the nearest second of arc, and their distances in kilometres from Tokyo. Following this is a table of twenty-two earthquakes sensible in Tokyo during the period under consideration. It would be an improvement if the headings to the columns in this table were given in English as well as in Japanese. Next is a map on a square of approximately $3^{\circ}$ edge having Tokyo at the centre, showing the distribution of the epicentres. It is notable that these are elongated in a direction north-east-south-west, and otherwise fairly uniformly distributed. Eight are submarine and off the north-east coast of the main island of Japan. Finally there are twelve reproductions of seismograms from the Tokyo (Hongo) station for the shocks of February 7, May 23 and June 6, six being normal and six acceleration seismograph diagrams, all very well reproduced. The publication provides valuable data for seismological studies.

\section{The Smithsonian Institution}

THE report of the Secretary of the Smithsonian Institution for the year ended June 30, 1938, refers to the completion in June of two full years of the Smithsonian radio programme in co-operation with the United States Office of Education (Publication 3489. Pp. viii + 117. Washington, D.C. : Government Printing Office, 1938). These educational broadcasts have covered the various fields of the Institution's activities-science, invention, history and art-and have been widely popular. An outstanding accession to the National Museum has been a collection of molluses obtained through the Francis Lea Chamberlain fund, which numbered more than a million specimens. Numerous specimens were brought back for the National Zoological Park by the National Geographic Society-Smithsonian Expedition to the East Indies. The Bureau of American Ethnology dispatched an expedition to South America to make extensive studies of the Indian tribes of the western part of that continent. The Division of Radiation and Organisms has developed an improved method for measuring plant growth substances concerned in the bending of plants towards the light, as well as a new automatic apparatus for measuring and recording photosynthesis continually, and an apparatus for the determination of chorophyll. The Smithsonian solar observing station on Mount St. Katherine in Egypt was abandoned, and construction of a new station on Burro Mountain, near Tyrone, New 
Mexico, was begun. The Astrophysical Observatory has undertaken the re-computation of all solar-constant values from 1923 to the present time.

\section{Academy of Sciences of the U.S.S.R.}

Aт a plenary session of the Academy of Sciences of the U.S.S.R. recently held in Moscow the following officers were elected: President, V. L. Komarov; Vice-Presidents, O. J. Schmidt, I. M. Gubkin, E. A. Chudakov, A. A. Bogomolets, A. J. Vishinsky, T. D. Lysenko, V. N. Obraztsov, A. E. Fersman. The secretaries of the eight newly constituted departments of the Academy, elected at a previous session of the Academy, become ex-officio members of the Presidium. They are: Department of Economics and Law, E. S. Varga; Department of Technical Sciences, V. P. Nikitin ; Department of History and Philosophy, A. M. Deborin ; Department of Geology and Geography, P. I. Stepanov; Department of Biology, L. A. Orbeli; Department of PhysicoMathematical Sciences, A. N. Kolmogorov; Department of Languages and Literature, I. I. Meshchaninov; Department of Chemistry, A. N. Bakh.

\section{Scholarships in Electrical Engineering}

Applications, which must be received not later than April 15, are invited for the following scholarships awarded by the Institution of Electrical Engineers: Duddell Scholarship (£150 per annum, tenable for three years), open to British subjects less than nineteen years of age on July 1, 1939, who wish to take up a whole-time day course in electrical engineering; Ferranti Scholarship ( $\$ 250$ per annum, tenable for two years), open to British subjects less than twenty-six years of age on July 1, 1939, who are students or graduates of the Institution and have been such for not less than two years, who desire to carry out whole-time research or postgraduate work of an electrical engineering nature; Swan Memorial Scholarship (£120, for one year), open to British subjects less than twenty-seven years of age on July 1, 1939, who have completed a recognized course in electrical engineering or science of at least three years, and who desire to carry out whole-time research or postgraduate work of an electrical engineering nature; Silvanus Thompson Scholarship ( $£ 100$ per annum and tuition fees, tenable for two years) for works employees who are the sons of parents of limited means, open to British subjects less than twentytwo years of age on July 1, 1939; the successful candidate will be required to make up a wholetime day course in electrical engineering at an approved university or technical college. Further information can be obtained from the Secretary, Institution of Electrical Engineers, Savoy Place, London, W.C.2.

\section{Announcements}

Prof. Joed H. Hildebrand, professor of chemistry in the University of California, has been awarded the Nichols Medal of the New York Section of the American Chemical Society.
M. Bernard Lyot, of the Meudon Observatory, has been elected a member of the Section of Astronomy of the Paris Academy of Sciences in succession to the late A. de La Baume Pluvinel.

DR. J. M. Stagg has been appointed superintendent of Kew Observatory, Richmond, in succession to Dr. F. J. W. Whipple, who retired on March 31 .

The Masters Memorial Lectures of the Royal Horticultural Society will be delivered in the Society's New Hall in Greycoat Street, Westminster, on April 18 and 19 at 3.30 p.m. by Dr. J. C. Willis, on "How Plants have found their Homes".

At a meeting of the Microchemical Club on March 11 the following officers were elected: Hon. Treasurer, Dr. L. H. N. Cooper ; Hon. Secretary, Mr. W. F. Stephenson; Hon. Librarian, Miss I. Hadfield; Members of Committee, Miss M. Corner and Mr. J. R. P. O'Brien.

THe American Social Hygiene Association has awarded the 1939 William Freeman Snow Medal to Dr. Thomas Parran, Surgeon-General, United States Public Health Service, "for his great contribution to the health and happiness of the American People through his persistent efforts against syphilis and the conditions which favour its spread".

AN informal conference on "Internal Strains in Solids" will be held during July 11-13 at the H. H. Wills Physical Laboratory, University of Bristol, under the joint auspices of the Physical Society and the University of Bristol. The Conference is open to all members of universities or research institutions. Further information can be obtained from Prof. N. F. Mott, H. H. Wills Physical Jaboratory, The University, Royal Fort, Bristol 8.

The thirty-seventh annual meeting of the South African Association for the Advancement of Science will be held in East London during July 3-8, under the presidency of Prof. G. H. Stanley. The British Association Medal for 1938 will be awarded to Miss Jean Murray, of the Division of Plant Industry, Pretoria, for her paper entitled "An Investigation of the Inter-relationship of Vegetation, Soils and Termites". A symposium on "The Need for the Investigation and Conservation of Human Resources in South Africa" is being organized by Dr. E. G. Malherbe, director of the National Bureau of Education and Social Research, Pretoria. Further information can be obtained from the assistant general secretary, Mr. H. A. G. Jeffreys, P. O. Box 6894, Johannesburg.

In the ninth report of the Committee for Atomic Weights of the International Union of Chemistry, the only change proposed is the atomic weight of phosphorus, which is now taken as $30 \cdot 98$. 